\section{Humor appreciation and issue involvement}

\author{
BARBARA GROTE and GEORGE CVETKOVICH \\ Western Washington State College, Bellingham, Wash. 98225
}

Female undergraduate students who were personally involved with the issue of women's rights were exposed to one of four experimental conditions. In Condition 1 (relevant humor), $S$ listened to a tape recording of humorous monologues in which women were the brunt of the jokes. Tape 2 (nonrelevant humor) presented humorous monologues not involving women. Tapes 3 and 4 presented nonhumorous material. Respectively, these were a relevant tape in which selections from a handbook of women's rights were read and a nonrelevant tape presenting a recording of the poem For Whom the Bell Tolls. A behavioral measure of change in personal involvement with the relevant issue and subjective evaluations of the recordings and own emotions show that $S$ appreciated the relevant humor but evidently did not experience decreased involvement with the theme of women's rights. Indeed, the relevant humor seemed to have the opposite effect of intensifying S's commitment to the theme. These findings suggest that intellectual appreciation of humor can occur in the absence of emotional or cognitive reinterpretation of the material. Furthermore, they support the notion that simple distraction may be the key variable operating to reduce issue involvement following humor.

Many writers have emphasized the cathartic or relief-like effect of humor. Lorenz (1967), for instance, has even gone so far as to suggest humor as a major avenue to reducing international conflict. The theoretical treatments of this supposed effect are diverse. Freud (1960), taking a basically emotional approach, suggests that people use humor as a socially acceptable way to express hostile or scatological feelings and thus "use up" these sources of anxiety. Relief theory (Berlyne, 1968), typically taking a more cognitive approach, suggests that a situation is funny because it provides a humorous treatment of a normally stressful theme and thereby promotes a reinterpretation in which the threatening element of the theme is no longer seen as dangerous but as ludicrous. A third interpretation (Landy \& Mettee, 1969) is simply that the appreciation of humor is incompatible with the feelings of aggression or anxiety.

Some experimental evidence exists supporting the cathartic effects of humor (Dworkin \& Efran, 1967 , Redlich \& Levine, 1960; Shurcliff, 1968; Singer, 1968). It is conceivable, however, that under certain circumstances, humor could have the opposite effect of promoting rather than relieving stress. Redlich \& Levine (1960) state that for a joke concerning a certain theme to be humorous for a person, that theme must be neither completely free of conflict nor associated with conflicts that are so great as to be "thoroughly repressed." A study by Levine \& Abelson (1959), using clinical Ss, supports this point. Psychiatric patients were found to dislike cartoons which were rated by their psychiatrists as turning on themes which were disturbing to the humor had a disturbing rather than a cathartic effect.

It can, of course, be argued that for humor to have a stress-relieving effect, it must be appreciated. Wolfenstein (1954) states that a playful, somewhat disengaged psychological stance is necessary for appreciation of humor. Since the highly involved Ss in the Levine and Abelson study did not appreciate the cartoons, we would perhaps expect no relief effect. In the present study, however, using nonclinical Ss, we find appreciation of humor which turns on a theme in which the Ss are involved, but a concomitant absence of any cathartic-like effects. Indeed, the humor seems to have the opposite effect of intensifying the Ss' commitment to the theme. METHOD

Thirty-six female introductory psychology students were selected as Ss on the basis of their high positive attitudes toward the Women's Rights Movement. ${ }^{1}$ Ss were assigned according to availability for scheduled experimental sessions to one of 17 2-to-3-person discussion groups. Each group was first asked to complete one of two tasks. Task $A$ required $S$ to guidance counselor helping a female freshman plan her course of studies. The student was described as a very intelligent girl with great academic potential. The student, however, because many people believe that it is unfeminine to be an "academic achiever," wants to take courses from secretarial and home economics rather than college preparatory curriculum. Ss' task was to think collectively of as many different arguments or statements as she could which could patients. Thus, in this case, attempted imagine that she was a high school be used to persuade the student to work towards a career compatible with her talents.

Task $B$ required $S$ to imagine that she represented a Women's Rights organization and had been asked to address a men's group on the topic of women's liberation. Ss were told that "the men were neither hostile, nor extremely receptive, but just mostly curious about the women's rights movement." Ss were asked to think collectively of as many different points as they could which might persuade the men that the movement was necessary and justified.

Following the first task, Ss completed the Nowlis-Green (1965) Mood Adjective Checklist (MACL), which is a self-report on present emotional state. They then listened to one of four tape recordings. These were: (1) a relevant-humor tape consisting of cuts from the album David Steinberg Disguised as a Normal Person; women were the brunt of the jokes in these monologues; (2) a nonrelevant-humor tape consisting of cuts from the same Steinberg album, but not having women as their topic; (3) a relevant-nonhumor tape consisting of the reading by a male of an edited essay on legal discrimination against women taken from Sisterhood is Powerful (Morgan, 1970); and (4) a nonrelevant-nonhumor tape taken from a recording of Orson Welles reading John Donne's poem For Whom the Bell Tolls. Length of tapes in each condition was approximately equal ( $\overline{\mathrm{X}}=12 \mathrm{~min}$ ).

After listening to one of the tapes, $\mathrm{S}$ completed the MACL for a second time and then rated the tape on 7-point bipolar adjective scales for (1) interest, (2) enjoyment, (3) funniness, (4) pro-womenness, and (5) how much she laughed. Finally, Ss completed either the guidance counselor or the women's rights task, depending on which they had worked on earlier. Order of the two tasks was reversed for approximately half the groups in each tape condition.

\section{RESULTS}

Mean ratings on the five evaluative scales received by each of the four tapes are presented in Table 1 . These ratings confirm the effectiveness of the tapes in producing expected effects upon Ss. Results of a 2 ( humor/non humor) by 2 (relevant/nonrelevant) ANOVA for each set of ratings were: (1) For the interest scale, a significant main effect for humor/nonhumor $(\mathrm{F}=6.3$, $\mathrm{p}<.02)$ reflects greater interest in the serious tapes. (2) No significant main or interaction effects were found for the enjoyment ratings. (3) Humor tapes, reasonably enough, were rated as significantly funnier than nonhumor 
Table 1

Mean Evaluation of Tape Recordings

\begin{tabular}{lcccccc}
\hline & & \multicolumn{5}{c}{ Evaluation } \\
\cline { 4 - 7 } $\begin{array}{l}\text { Description } \\
\text { of Tape }\end{array}$ & $\begin{array}{c}\text { Number } \\
\text { of Groups }\end{array}$ & Interest & Enjoyment & Funny & Pro-woman & Laughter \\
\hline $\begin{array}{l}\text { Relevant- } \\
\text { Humor }\end{array}$ & 4 & 2.75 & 3.88 & 3.38 & 2.06 & 2.63 \\
$\begin{array}{l}\text { Nonrelevant- } \\
\text { Humor }\end{array}$ & 4 & 2.25 & 4.25 & 2.63 & 3.50 & 4.13 \\
$\begin{array}{l}\text { Relevant- } \\
\text { Nonhumor }\end{array}$ & 5 & 5.54 & 4.55 & 1.73 & 6.18 & 2.55 \\
$\begin{array}{l}\text { Nonrelevant- } \\
\text { Nonhumor }\end{array}$ & 4 & 4.22 & 3.67 & 1.00 & 3.56 & 1.11 \\
\hline
\end{tabular}

tapes $(F=11.8, p<.002)$. (4) A significant main effect for humor/nonhumor $(F=7.7, p<.04)$ and a significant two-way interaction $(\mathrm{F}=7.6, \quad \mathrm{p}<.01)$ reflects no difference in reported laughter to the nonhumor tapes, more laughter to the humor than to the nonhumor tapes, but greater reported laughter to the nonrelevant - than to the relevant-humor tape. (5) The relevant-humor tape was rated more a $n t$ i w o m e $n$ t h n the relevant-nonhumor tape, while the two nonrelevant tapes were rated as equally neutral to women (humor/nonhumor: $F=30.4$ $\mathrm{p}<.0001 ;$ relevant/nonrelevant: $\mathrm{F}=$ $5.3, \mathrm{p}<.03$; interaction: $\mathrm{F}=24.3$, p $<.0001$ ).

It was assumed that increased commitment to the issue of women's rights would be revealed by a greater number of persuasive statements developed for the task following the tape, relative to the number of statements given to the task preceding the tape. Since no significant effect for content of task (guidance counselor vs women's rights speaker) was found across the tape conditions, this distinction is disregarded in the following analysis.

Analysis of difference in number of persuasive statements given before and after listening to the tape in each of the conditions revealed a significant interaction effect between the $\mathrm{h} u \mathrm{mor} / \mathrm{n}$ on $\mathrm{h}$ mor and relevant/nonrelevant variables $(F=$ $8.8, \mathrm{p}<.05)$. Groups of $\mathrm{Ss}$ who listened to the relevant-humor recording made an average of five more statements on the second task. By comparison, $\mathrm{S}$ who heard either of the nonhumor tapes made only 1.25 more statements, while Ss hearing the nonrelevant-humor tape made an average of .5 fewer statements. DISCUSSION

The result of the nonrelevant-humor condition of the present study corroborate previous findings of Dworkin and Efran and of Landy and Mettee. These investigators angered their $\mathrm{Ss}$ and then exposed them to humor which was not relevant to the conditions of arousal. In line with present results, these previous studies found that nonrelevant humor mitigates aggressive feelings. Since in all three of these cases, humor was not relevant to the theme of S's involvement, it is difficult to interpret the findings as a catharsis or relief phenomenon. Nonhostile, nonrelevant humor should neither provide a socially acceptable means of expressing hostile feelings nor promote a cognitive restructuring of the situation. It seems more likely that an interpretation such as that proposed by Landy and Mettee and also favored by Bandura (1969) is more suitable. This is the idea that humor merely distracts attention from the causes of aggressive feelings or that humor appreciation and aggression are incompatible emotions.

The relevant-humor condition of the present study is structurally similar to conditions used in the 1959 study by Levine \& Abelson (1959) in that the humor used was calculated to be, to some degree, disturbing to $\mathrm{Ss}$. However, while Levine and Abelson used humor that was supposedly highly threatening, the relevant humor used here was, at most, insulting. Therefore, it can be expected that the experience of $\mathrm{Ss}$ listening to the relevant-humor tape may have been on a more cognitive level than was the experience of the Levine and Abelson Ss. It is not surprising, then, that the apparently well-adjusted college students in the present study could appreciate, on an intellectual level, a skillful presentation by a popular comedian. The interesting aspect of this condition is that, in spite of their intellectual appreciation, Ss were emotionally aroused, indeed evidently angered, by the relevant humor.

Analysis of changes in reported mood as recorded on the Nowlis-Green MACL support this point by showing that Ss in the relevant tape conditions became significantly more "defiant" $\left(x^{2}=13.7, p<.05\right)$ after listening to the tape than did $S s$ in the other conditions. Additionally, these Ss report becoming more "angry" $\left(x^{2}=\right.$ 11.7, $\mathrm{p}<.10$ ) and more "clutched up" $\left(x^{2}=10.3, p<.10\right)$.

When $S s$ in the relevant-humor condition were given a second opportunity to express their attitude towards women's rights, exposure to the mildly insulting humor had aroused them to more intense involvement with the issue. This finding is particularly interesting when compared to the effects of the relevant-nonhumor tape. While the relevant-nonhumor tape was rated as significantly more interesting than the relevant-humor tape, presented documented evidence of discrimination against women, and provided several arguments Ss might have used in completing the second task, it did not have the radicalizing effect of the insulting humor. In fact, Ss in this condition gave no more statements in support of women's rights on their second task than did Ss who had heard For Whom the Bell Tolls.

\section{REFERENCES}

BANDURA, A. Principles of behavior modification. New York: Holt, Rinehar \& Winston, 1969

BERLYNE, D. E. Laughter, humor, and play. In $G$. Lindzey and $E$. Aronson (Eds.), Handbook of social psychology. Vol. 3. Reading, Mass: Addison-Wesley. 1968. P. 802

DWORKIN, E., \& EFRAN. J. The angered: Their susceptibility to varieties of humor Journal of Personality \& Social Psy chology, 1967, 6, 233-236.

FREUD, S. Jokes and their relationship to the unconscious. In S. Freud, Complete works. Vol. 8. (Standard ed.) London: Hogarth, 1960.

LANDY, D. \& METTEE, D. Evaluation of an aggressor as a function of exposure to cartoon humor. Journal of Personality \& Social Psychology, 1969, 12, 66-71.

LEVINE, J., \& ABELSON, R. Humor as a disturbing stimulus. Journal of Genetic Psychology, 1959, 60, 191-200.

LORENZ, K. On aggression. New York: Bantam, 1967. Pp. 28 3-287.

MORGAN, R. Sisterhood is powerful. New York: Random House, 1970.

NowLIS, V. Research with the mood adjective check list. In $\mathrm{S}$. Tomkins and $\mathrm{C}$. Izards (Eds.), Affect, cognition, and personality: Empirical studies. New York: Springer, 1965. Pp. 352-389.

REDLICH, F., \& LEVINE, J. Intellectual and emotional factors in the appreciation of humor. Journal of Genetic Psychology, $1960,62,25-35$

SHURCLIFF, A. Judged humor, arousal, and the relief theory. Journal of Personality \& Social Psychology, 1968, 8, 360-363.

SINGER, D. Aggression arousal, hostile humor, catharsis. Journal of Personality \& Social Psychology Monograph Supplement, Part 2, 1968, 1-14.

WOLFENSTEIN, M. Children's humor: A psychological analysis. Glencoe, Ill: Free Press, 1954.

NOTE

1. Details of $S$ selection and a copy of the women's rights attitude questionnaire are available upon request. Mean of Ss' attitude scores was $1.29 \mathrm{SD}$ above the mean of all female college students tested $(\mathrm{N}=131)$. 